\title{
Importance of amino acid composition to improve skin collagen protein synthesis rates in UV-irradiated mice
}

\author{
Hitoshi Murakami $\cdot$ Kazutaka Shimbo • \\ Yoshiko Inoue • Yoshinobu Takino • \\ Hisamine Kobayashi
}

Received: 16 May 2011/Accepted: 8 August 2011/Published online: 23 August 2011

(C) The Author(s) 2011. This article is published with open access at Springerlink.com

\begin{abstract}
Skin collagen metabolism abnormalities induced by ultraviolet (UV) radiation are the major causes of skin photoaging. It has been shown that the one-time exposure of UV irradiation decreases procollagen mRNA expression in dermis and that chronic UV irradiation decreases collagen amounts and induces wrinkle formation. Amino acids are generally known to regulate protein metabolism. Therefore, we investigated the effects of UV irradiation and various orally administered amino acids on skin collagen synthesis rates. Groups of 4-5 male, 8-week-old HR-1 hairless mice were irradiated with UVB $\left(66 \mathrm{~mJ} / \mathrm{cm}^{2}\right)$ twice every other day, then fasted for $16 \mathrm{~h}$. The fractional synthesis rate (FSR; $\% / \mathrm{h}$ ) of skin tropocollagen was evaluated by incorporating $\mathrm{L}-$ [ring ${ }_{-}^{2} \mathrm{H}_{5}$ ]-phenylalanine. We confirmed that the FSR of dermal tropocollagen decreased after UVB irradiation. The FSR of dermal tropocollagen was measured $30 \mathrm{~min}$ after a single oral administration of amino acids $(1 \mathrm{~g} / \mathrm{kg})$ to groups of 5-16 UVB-irradiated mice. Branched-chain amino acids (BCAA, $1.34 \pm 0.32$ ), arginine (Arg, $1.66 \pm 0.39$ ), glutamine (Gln, $1.75 \pm 0.60$ ), and proline (Pro, $1.48 \pm 0.26$ ) did not increase the FSR of skin tropocollagen compared with
\end{abstract}

H. Murakami ( $₫) \cdot$ K. Shimbo · Y. Inoue · H. Kobayashi

Frontier Research Laboratories, Institute for Innovation,

Ajinomoto Co., Inc, 1-1 Suzuki-cho,

Kawasaki 210-8681, Japan

e-mail: hitoshi_murakami@ajinomoto.com

Y. Takino

Research Institute for Bioscience Products and Fine Chemicals,

Ajinomoto Co., Inc, 1-1 Suzuki-cho,

Kawasaki 210-8681, Japan distilled water, which was used as a control $(1.56 \pm 0.30)$. However, essential amino acids mixtures (BCAA + Arg + Gln, BCAA + Gln, and BCAA + Pro) significantly increased the FSR $(2.07 \pm 0.58,2.04 \pm 0.54,2.01 \pm 0.50$ and $2.07 \pm 0.59$, respectively). This result suggests that combinations of BCAA and glutamine or proline are important for restoring dermal collagen protein synthesis impaired by UV irradiation.

Keywords Amino acids - Skin collagen ·

Protein synthesis rate $\cdot$ UV-irradiated rat

$\begin{array}{ll}\text { Abbreviations } \\ \text { UV } & \text { Ultraviolet } \\ \text { FSR } & \text { Fractional synthesis rate } \\ \text { AP-1 } & \text { Activator protein 1 } \\ \text { TGF-b } & \text { Transforming growth factor-beta } \\ \text { EGF } & \text { Epidermal growth factor } \\ \text { IL1 } & \text { Interleukin 1 } \\ \text { TNF-a } & \text { Tumor necrosis factor-alpha } \\ \text { mTOR } & \text { Mammalian target of rapamycin } \\ \text { p70S6K } & \text { 70 kDa ribosomal protein S6 kinase } \\ \text { 4E-BP1 } & \text { Eukaryotic initiation factor-binding protein 1 } \\ \text { GAPP } & \text { Glutamate-dependent protein phosphatase } \\ \text { BCAA } & \text { Branched-chain amino acids } \\ \text { Leu } & \text { Leucine } \\ \text { Ile } & \text { Isoleucine } \\ \text { Val } & \text { Valine } \\ \text { Gln } & \text { Glutamine } \\ \text { Arg } & \text { Arginine } \\ \text { Pro } & \text { Proline } \\ \text { EAA } & \text { Essential amino acids } \\ \text { Glu } & \text { Glutamate } \\ \text { DW } & \text { Distilled water }\end{array}$




\section{Introduction}

Skin aging, especially wrinkling and sagging, is induced by several factors, including ultraviolet (UV) irradiation, dryness, chemical stimulation, malnutrition, and exposure to activated oxygen species (Rittie and Fisher 2002). In particular, UV radiation is a potent agent of skin aging, and many reports suggest that chronic UV irradiation damages the skin protein and induces wrinkle formation in humans and animals (Boyer et al. 1992; Fisher et al. 2000, 2001; Rittie and Fisher 2002; Takema et al. 1996). Dermal collagen is a major component of skin dermis and is necessary to maintain skin structure. UV irradiation stimulates several factors, such as AP-1, TGF- $\beta$, EGF, IL1, and TNF- $\alpha$, that affect collagen metabolism. Fischer has reported that in humans, procollagen mRNA levels are decreased and matrix metalloprotease mRNA levels are increased by single UV irradiation (Fisher 2005; Fisher et al. 2000, 2001). Takema found that in mice, chronic UV irradiation decreases the dermal collagen protein, resulting in wrinkle formation (Takema et al. 1996). These articles indicated that the decrease in dermal collagen protein resulting from chronic UV stimulation is one of the main causes of skin aging (Rittie and Fisher 2002). Cellular protein levels are regulated by protein turnover processes, such as protein synthesis and breakdown. However, there has been little study of the impact of UV irradiation on dermal collagen protein synthesis rates. To maintain steady dermal collagen levels, it is important to correct changes in the protein turnover rate induced by UV irradiation.

Amino acids are protein substrates and regulators of protein metabolism and are highly safe for humans. In an in vitro study, Bellon et al. $(1995,1987)$ found that glutamine increases procollagen mRNA levels and collagen content, and suggested that de novo proline synthesis from glutamine is important for collagen synthesis. Proline and its precursors, glutamate and pyrroline-5-carboxylate, increase collagen synthesis in human fibroblast cells (Karna et al. 2001). Some amino acids, such as arginine (Shi et al. 2003; Stechmiller et al. 2005) and ornithine (Shi et al. 2002), and amino acid mixtures (Badiu et al. 2010; Corsetti et al. 2010) enhance wound healing in rats. Zhang also indicated that leucine supplementation has an anabolic effect on protein metabolism in skin wounds in rabbits (Zhang et al. 2004). However, few studies have focused on amino acids' ability to restore dermal collagen synthesis after UV irradiation. UV irradiation and wounds provoke different healing responses (Fisher 2005; Johnstone and Farley 2005).

Consequently, the present study was performed to investigate the effects of UVB irradiation on the FSR of mouse skin collagen and to investigate which amino acids can correct these FSR changes.

\section{Methods}

Animals

This study was approved by the Institutional Animal Care and Use Committee of Ajinomoto Co., INC. Nine-weekold male HR-1 hairless mice (Sankyo lab service Co. Japan) were housed in a temperature-controlled room with a 12-hour light and dark cycle. The animals were given standard commercial chow (CR-F1, Charles River, Japan) and water ad libitum.

\section{UV irradiation}

UVB radiation was generated with a bank of six sun lamps (FL20S-E-30/DMR, 20W, peak emission near $305 \mathrm{~nm}$; Toshiba Medical Supply, Tokyo, Japan). The minimal erythema dose (MED) determined $24 \mathrm{~h}$ after UV irradiation was $66 \mathrm{~mJ} / \mathrm{cm}^{2}$.

\section{Experimental design}

The first experiment investigated the effect of UVB irradiation on the FSR of skin tropocollagen. Mice (four or five in each group) were irradiated with UVB $\left(66 \mathrm{~mJ} / \mathrm{cm}^{2}\right)$ on the dorsal skin one, two, three, or four times at a one-day intervals. The FSR was evaluated using the flooding dose method described by Garlick and McNurlan (1998). After $16 \mathrm{~h}$ of fasting after the last UV irradiation, the mice were injected in the tail veins with flooding doses of phenylalanine $(1.5 \mathrm{mmol} / \mathrm{kg}$ body weight $)$ containing $\mathrm{L}$-[ring- ${ }^{2} \mathrm{H}_{5}$ ]phenylalanine (50 mol percent excess, Cambridge isotope, Cambridge, MA). The mice were killed by decapitation 5 min after the phenylalanine injection. Blood was then collected from the necks, and the dorsal skins were removed. Subcutaneous skin fat was immediately removed, and the dermis was frozen in liquid nitrogen and stored at $-80^{\circ} \mathrm{C}$. Blood was separated from plasma by centrifugation at $3,000 \mathrm{~g}$ for $15 \mathrm{~min}$ at $4^{\circ} \mathrm{C}$, and the plasma was stored at $-80^{\circ} \mathrm{C}$.

The second experiment investigated the effect of orally administered amino acids on the skin tropocollagen FSR of UV-irradiated mice. The mice's dorsal skins were irradiated with UVB $\left(66 \mathrm{~mJ} / \mathrm{cm}^{2}\right)$ twice every other day. After $16 \mathrm{~h}$ of fasting, different amino acid solutions $(1 \mathrm{~g} / \mathrm{ml} / \mathrm{kg}$ body weight) were orally administered by gastric tube to groups of 5-16 mice. The amino acid amount in the solutions was an amount commonly used in animal experiments to investigate acute amino acid effects (Farges et al. 1999; Smriga and Torii 2003). The compositions of the solutions are shown in Table 1 (all amino acids were manufactured by Ajinomoto Co., Inc.). Twenty-five minutes after the solutions were administered, the mice were 


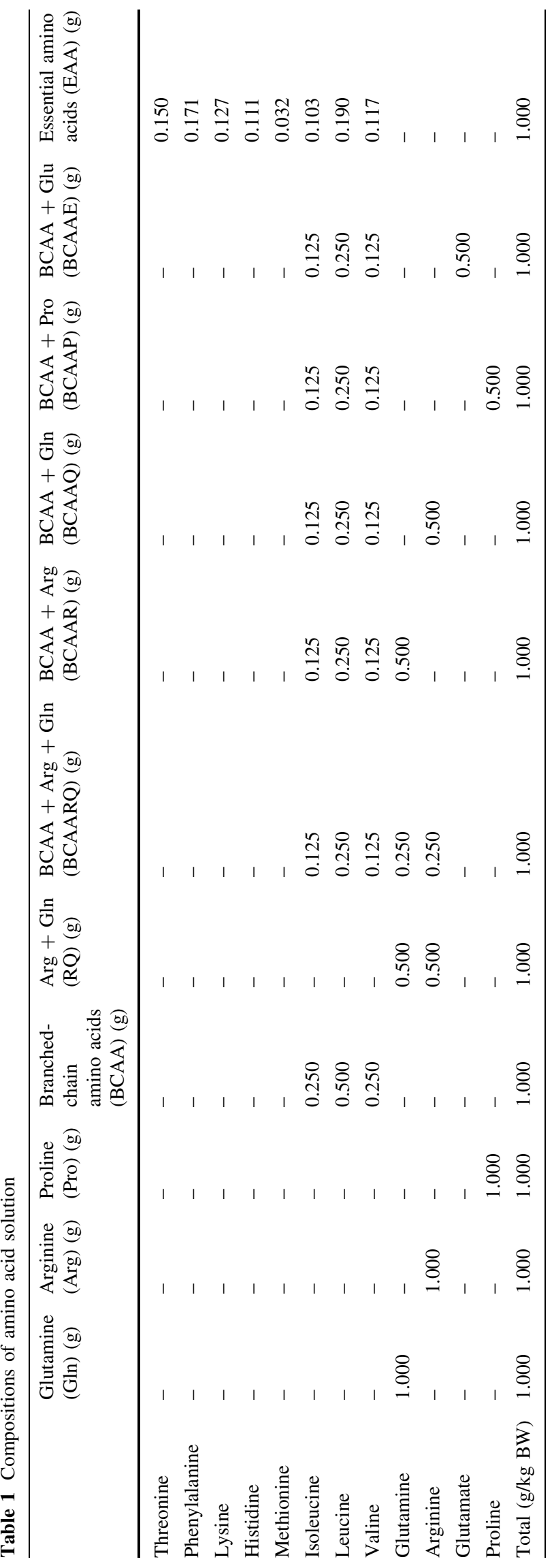

injected with flooding doses of phenylalanine, and skin and blood were collected as described above.

Sample preparation

Tropocollagen was extracted using a modification of Volpi's method (Volpi et al. 2000). Briefly, approximately $0.5 \mathrm{~g}$ of dorsal skin was homogenized on ice in Buffer A $(10 \mathrm{ml} / \mathrm{g}$ of skin), a pH 7.4 buffer containing $150 \mathrm{mM} \mathrm{NaCl}, 50 \mathrm{mM}$ Tris-HCl, $2 \mathrm{mM}$ EDTA, $1 \mathrm{mM}$ phenylmethylsulfonyl fluoride, $2 \mathrm{mM} \mathrm{N}$-ethylmaleimide, and $0.2 \mathrm{mM}$ 2-aminopropionitrile. The homogenized sample was shaken overnight at $4^{\circ} \mathrm{C}$, and then centrifuged at $7,500 \mathrm{~g}$ for $10 \mathrm{~min}$ at $4^{\circ} \mathrm{C}$. The supernatant was filtered with a $75-\mathrm{mm}$ mesh, brought to $4.5 \mathrm{M}$ with $\mathrm{NaCl}$, and shaken for $5 \mathrm{~h}$. The solution was centrifuged at $70,000 \mathrm{~g}$ for $30 \mathrm{~min}$ at $4^{\circ} \mathrm{C}$. The precipitate was dissolved in Buffer $\mathrm{B}$, a $\mathrm{pH} 7.6$ buffer containing $200 \mathrm{mM} \mathrm{NaCl}, 50 \mathrm{mM}$ Tris- $\mathrm{HCl}$, and $2 \mathrm{mM}$ EDTA, and the solution was dialyzed in Buffer B for $2 \mathrm{~h}$. This dialyzed sample, which included large amounts of skin tropocollagen, was hydrolyzed with hydrochloric acid for $16 \mathrm{~h}$ at $90^{\circ} \mathrm{C}$, and the hydrolysate was used to measure isotope incorporation rates in the tropocollagen. To confirm the purity of the extracted tropocollagen, the dialyzed sample was subjected to SDS-PAGE (E-pagell, gradient gel 5-20\%, ATTO, Japan) using a molecular mass standard (Bio-Rad, USA). Two wells were loaded with same amounts of the same samples. One was stained with Coomassie Brilliant Blue to detect proteins, and the other was blotted on nitrocellulose to identify collagen proteins using Western blotting with a mixture of antibody anti-collagen types I, III, and VII (Calbiochem, USA).

Approximately $0.04 \mathrm{~g}$ of dermal skin was homogenized with $15 \%$ sulfosalicylic acid, and the homogenate was centrifuged at $10,000 \mathrm{~g}$ for $10 \mathrm{~min}$ at $4^{\circ} \mathrm{C}$. The supernatant was used as skin tissue fluid. The precipitate was hydrolyzed in $2 \mathrm{ml}$ of $6 \mathrm{~N} \mathrm{HCl}$ at $90^{\circ} \mathrm{C}$ for $16 \mathrm{~h}$ and was used as mixed skin protein.

Amino acids that included hydrolysates and tissue fluid were purified by cation exchange chromatography (Dowex 50W 8X; Bio-Rad Laboratories, USA) and dried in a rotary evaporator (Nakajima corp., Japan).

Analysis

Phenylalanine enrichment ( $\left.E_{\text {(skin free) }}\right)$ in the tissue fluid was determined by its tert-butyldimethylsilyl (t-BDMS, Pierce, USA) derivatization. Gas chromatography-mass spectrometry was used to monitor Ions 336 and 341 in the electron impact mode (GC-MS; 6890 GC system and 5473 Network mass selective detector, Agilent, USA). Phenylalanine enrichment in the tropocollagen and mixed skin protein samples ( $\left.E_{(\text {tropocollagen) }}, E_{\text {(mixed skin) }}\right)$ was 
determined by measuring their AQC-detergent (Waters, USA) derivatization using liquid chromatography-mass spectrometry to monitor ions 336 and 341 in the first MS and 171 in the second MS (LC-MS/MS; Prominence HPLC system, Shimazu, Japan and API 3200, Applied Biosystems, USA). Plasma insulin concentrations were measured using a commercial ELISA-kit (Morinaga Institute Biological Science, Japan), and amino acid concentrations were measured with an automatic amino acid analyzer (L-8500, Hitachi, Japan).

\section{Calculation and statistics}

The FSR of the skin tropocollagen and mixed skin protein was calculated with the precursor-product model. The precursor represented the free phenylalanine enrichment in the skin tissue fluid, and the product represented the enrichment of the phenylalanine-incorporated skin tropocollagen or mixed skin protein. The FSR was calculated as $\operatorname{FSR}(\% / \mathrm{h})=E_{(\text {tropocollagen or mixed skin) }} /\left(E_{(\text {skin free) }} \times t\right) \times$ 100 , where $t$ represents the time interval between phenylalanine injection and sampling.

Values are presented as means \pm SD. Comparisons with the control group (given distilled water, DW) were made via Dunnett's test after ANOVA for multiple comparison (JMP, SAS Institute, Cary, NC, USA). Values of $P<0.05$ were considered significant.

\section{Results}

Skin tropocollagen extracted from the dorsal skin was assayed with Western blotting to confirm its purity. The protein bands of extracted skin tropocollagen separated by SDS-PAGE corresponded to Type I, III, and VII collagen bands (Fig. 1). The purity of the extraction was confirmed as described in a previous article (Volpi et al. 2000).

The FSR of skin tropocollagen tended to decrease after UVB irradiation, especially for mice that were irradiated twice with a one-day interval between irradiations (Fig. 2). The effect of orally administered amino acid on the FSR in the dermal tropocollagen of UVB-irradiated mice is shown in Fig. 3. Thirty minutes after oral amino acid administration, $\mathrm{BCAA}+\mathrm{Arg}+\mathrm{Gln}, \mathrm{BCAA}+\mathrm{Gln}, \mathrm{BCAA}+$ Pro, and essential amino acids (EAA) significantly increased the FSR of skin tropocollagen compared with the control group $(2.04 \pm 0.54,2.01 \pm 0.50,2.07 \pm 0.59$ and $2.07 \pm 0.58 \% / \mathrm{h}$, respectively, in amino acid groups compared with DW, $1.47 \pm 0.21 \% / \mathrm{h}$ ). However, single amino acids (Arg, Gln or Pro: $1.66 \pm 0.39,1.73 \pm 0.67$ or $1.45 \pm 0.26 \% / \mathrm{h}$, respectively) and amino acid mixtures (BCAA, Arg + Gln or $\mathrm{BCAA}+$ Glu: $1.30 \pm 0.32,1.72 \pm 0.26$ or $1.74 \pm 0.34$, respectively) did not increase the FSR.

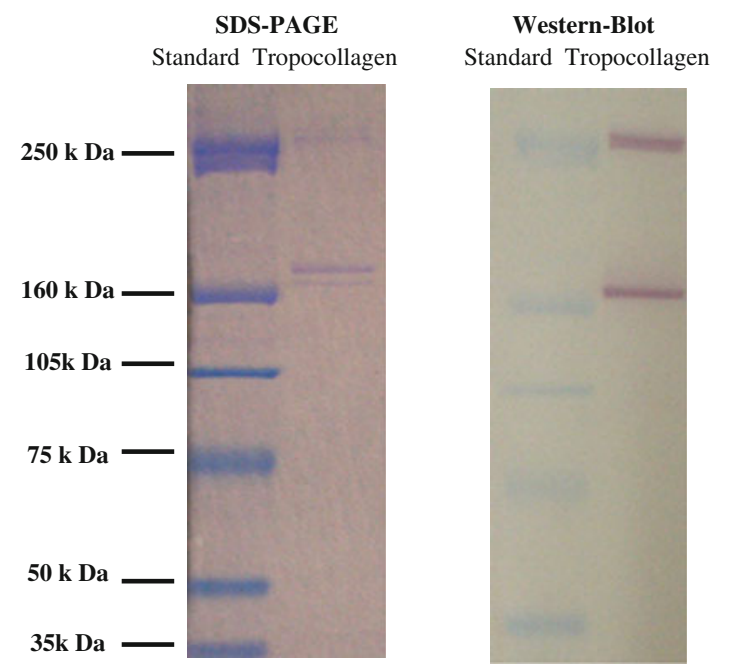

Fig. 1 SDS-PAGE and Western blot analysis of isolated skin tropocollagen fractions. Type I, III and VII collagen were identified using Western blot, and the purity of extracted collagen was confirmed. $s d$ Standard protein, and TP tropocollagen

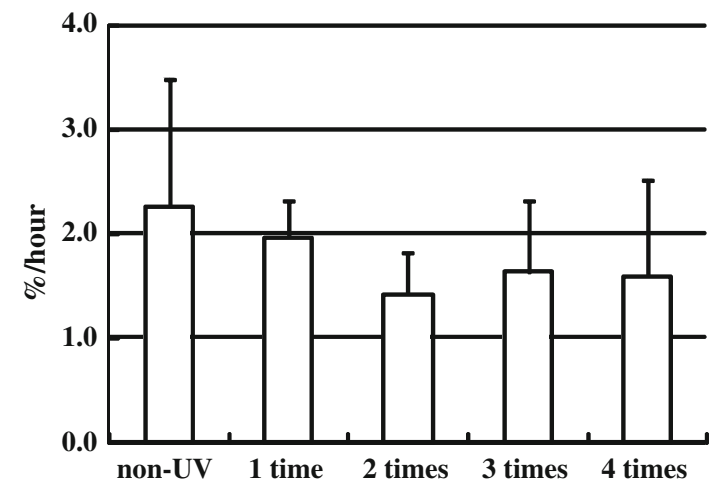

Fig. 2 Effect of UVB irradiation on the FSR of skin tropocollagen. Samples were irradiated with UVB one, two, three, or four times at one-day intervals. The FSR of tropocollagen decreased to its minimum value after two UVB irradiations. Values are means \pm SD

The effect of oral amino acid administration on the FSRs of mixed skin protein is shown in Fig. 4. The FSRs of mixed skin protein were increased by UVB irradiation. However, oral amino acid administration did not affect the FSRs.

Plasma insulin concentrations $30 \mathrm{~min}$ after oral amino acid administration are shown in Fig. 5. Arg + Gln significantly increased plasma insulin concentrations compared to the DW group $(1.14 \pm 0.61$ vs. $0.56 \pm 0.6 \mathrm{nag} / \mathrm{ml})$. However, there was no correlation between plasma insulin concentration and the FSR of skin tropocollagen $\left(r^{2}=0.0049\right.$; Fig. 6).

Plasma amino acid concentrations are shown in Table 2. Plasma branched-chain amino acid concentrations increased by approximately five times in the BCAA $+\mathrm{Arg}+\mathrm{Gln}$, 


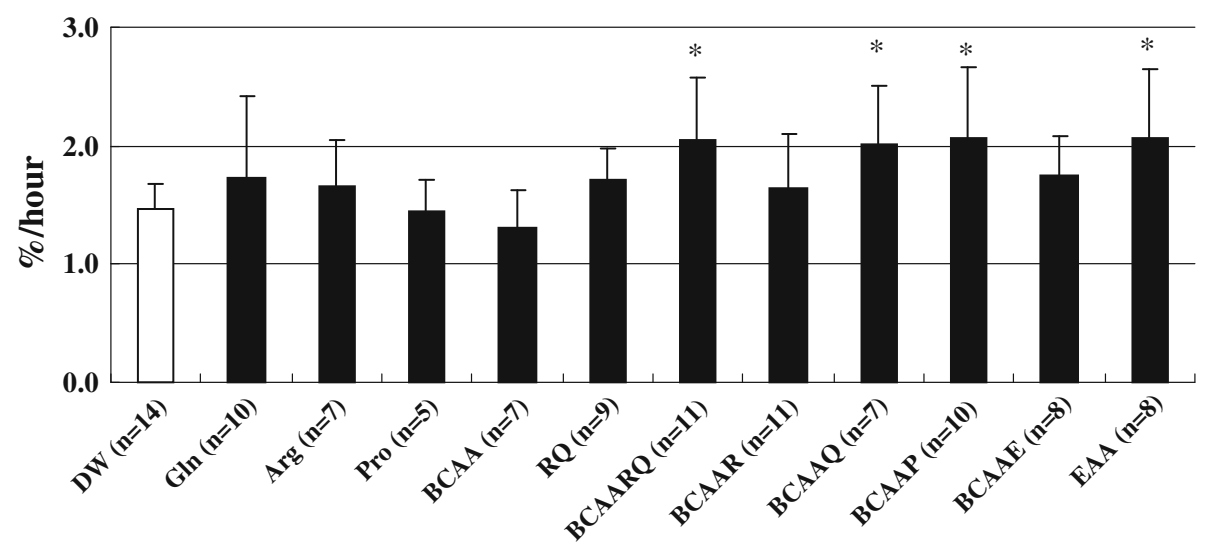

Fig. 3 Effect of orally administered amino acids on the FSR of skin tropocollagen in UVB-irradiated mice. $\mathrm{BCAA}+\mathrm{Arg}+\mathrm{Gln}$ (BCAARQ), BCAA + Gln (BCAAQ), BCAA + Pro (BCAAP) and an essential amino acid mixture (EAA) significantly increased the FSR of skin tropocollagen $30 \mathrm{~min}$ after oral administration, but single amino acids did not increase the FSR. It is necessary to include BCAA in amino acid mixtures to increase the FSR of skin tropocollagen. Values are presented as means \pm SD. Comparisons with the control group ( $D W$ distilled water) were carried out with a Dunnett's test after ANOVA for multiple comparison $(* P<0.05)$

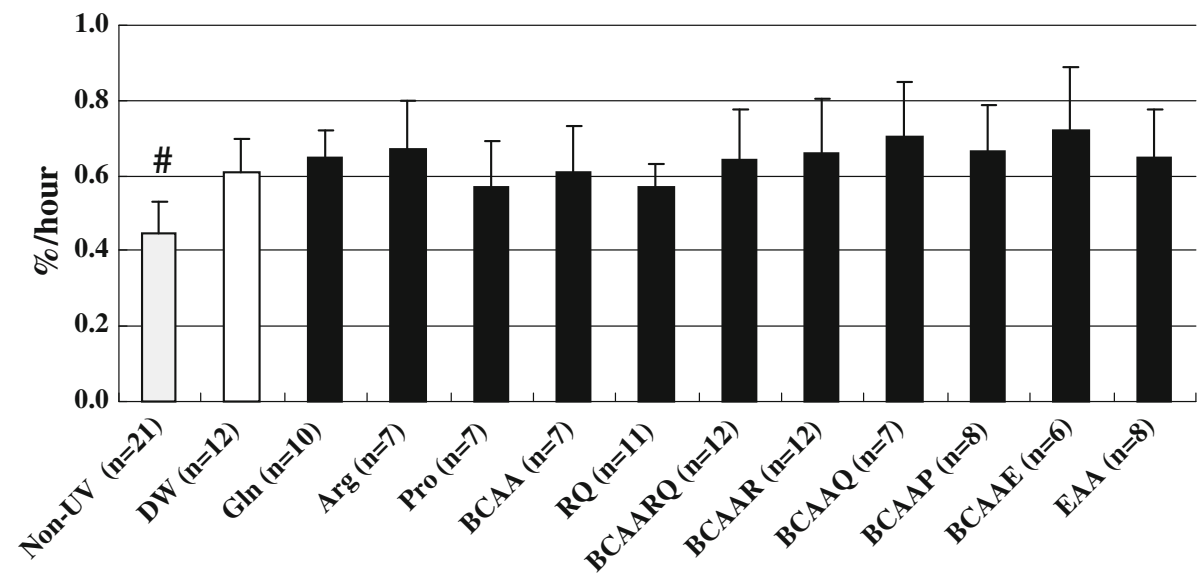

Fig. 4 Effect of orally administered amino acids on the FSR of mixed skin protein in UVB-irradiated mice. The FSR of mixed skin protein, including dermis and epidermis, was increased by UVB irradiation. This suggests that the synthesis rate of keratin, the most abundant protein in epidermis, increases with UVB irradiation.

BCAA + Arg, BCAA + Gln, BCAA + Pro, BCAA + Glu and EAA groups compared with the DW group. Plasma tryptophan, histidine, tyrosine, threonine, serine and especially, glycine concentrations decreased in the groups that received solutions containing BCAA. Plasma proline concentrations increased in the groups that received solutions containing proline and slightly increased in Arg and Arg + Gln groups.

\section{Discussion}

The object of this study was to investigate the effects of UV irradiation on the rate of skin tropocollagen protein synthesis and to determine which amino acid increases
Amino acids did not further increase the FSR of mixed skin protein. Values are presented as means \pm SD. Statistical comparisons with the control group (DW, distilled water) was carried out with a Dunnett's test after ANOVA for multiple comparisons $\left({ }^{\#} P<0.05\right)$

dermal tropocollagen protein synthesis in UV-irradiated mice. It was observed that the tropocollagen FSR generally decreased after UVB irradiation and that some amino acid mixtures, such as BCAA + Arg + Gln, BCAA + Gln, $\mathrm{BCAA}+\mathrm{Gln}+$ Pro, and a mixture of essential amino acids significantly increased the tropocollagen FSR in UVirradiated mice. This is the first paper to indicate which single amino acids or amino acid mixtures can correct UV irradiation-induced changes in collagen protein synthesis.

Decreasing amounts of collagen result in skin aging, such as formation of wrinkles and sagging skin, and the main cause of skin aging is UV irradiation (Takema et al. 1996). However, few studies have examined collagen protein metabolism. To help prevent skin aging, it is important to understand how UV irradiation induces 


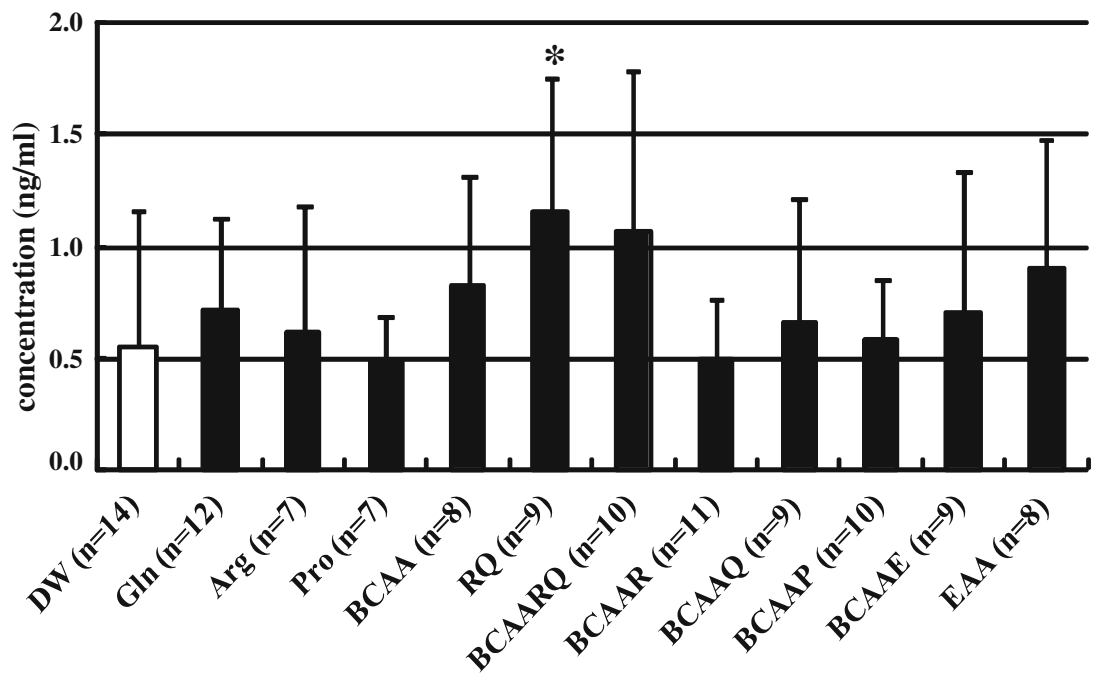

Fig. 5 Plasma insulin concentrations $30 \mathrm{~min}$ after oral amino acids administration to UVB-irradiated mice. Arg + Gln (RQ) significantly increased plasma insulin concentrations $30 \mathrm{~min}$ after oral administration. However, there was no correlation between plasma insulin concentration and the FSR of skin tropocollagen. We postulate that $\mathrm{BCAA}+\mathrm{Arg}+\mathrm{Gln}$ (BCAARQ), $\mathrm{BCAA}+\mathrm{Gln}$ (BCAAQ),
BCAA + Pro (BCAAP), and the essential amino acids mixture (EAA) increased the FSR of skin tropocollagen independently of insulin. Values are presented as means $\pm \mathrm{SD}$. Comparisons with the control group ( $D W$ distilled water) were conducted with a Dunnett's test after ANOVA for multiple comparison $(* P<0.05)$

protein metabolism, especially in investigating the effect of amino acid supplementation on collagen protein metabolism because proline stimulates collagen synthesis in human fibroblast cells (Bellon et al. 1987). For this reason, we used L-[ring- ${ }^{2} \mathrm{H}_{5}$ ]-phenylalanine as a tracer and a method involving extraction of tropocollagen to measure the collagen FSR. Phenylalanine is commonly used to investigate the effects of amino acid supplementation on protein metabolism. The FSR of tropocollagen tended to decrease after one-time UV irradiation, and a similar decrease was observed after additional UV irradiation (Fig. 2). This result corresponded to that obtained by Fisher et al. (2000), who found that human skin procollagen mRNA levels decreased with UV irradiation. Thus, it was confirmed that UVB irradiation also decreases the collagen protein synthesis rate.

Several amino acids used in the present study, such as EAA, BCAA, Gln, Glu, and Arg, have been reported to stimulate protein synthesis in several tissues in in vivo and in vitro studies (Anthony et al. 2000; Bellon et al. 1987, 1995; Kimball and Jefferson 2004; Krause et al. 2002a; Oehler and Roth 2003; Proud 2004; Stechmiller et al. 2005; Stoll et al. 1992; Tipton et al. 1999; Xu et al. 2001). In particular, Arg, Gln, and their metabolites increased collagen synthesis in vitro or in wound healing in rats (Bellon et al. 1987, 1995; Shi et al. 2002, 2003; Stechmiller et al. 2005). However, there is little information on the effect of amino acid on dermal collagen protein synthesis after UV irradiation. It is important to investigate UV irradiation's effect in mice because the process of collagen deposition 


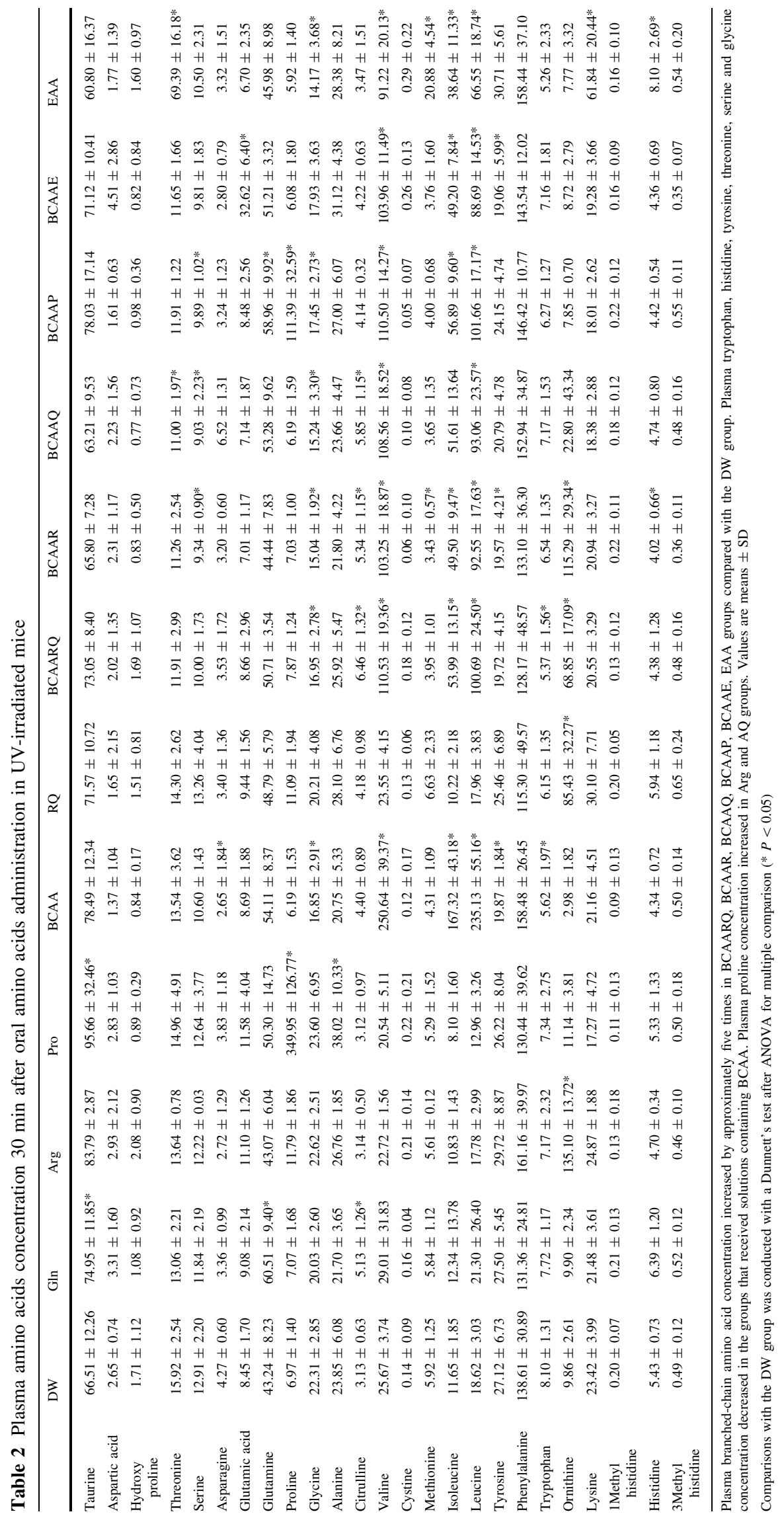


differs between UV irradiation and wounds (Fisher 2005; Johnstone and Farley 2005). Some amino acid mixtures containing BCAA, such as EAA, BCAA + Arg + Gln, $\mathrm{BCAA}+\mathrm{Gln}$, and BCAA + Pro, significantly increased the FSR of tropocollagen (Fig. 3). BCAA in particular, but also leucine and its metabolites, modulate mammalian targets of rapamycin (mTOR) and stimulate phosphorylation of the 70-kDa ribosomal protein S6 kinase (p70S6K) and eukaryotic initiation factor-binding protein-1 (4E-BP1), initiating translation and transcription in protein synthesis (Anthony et al. 2000; Kimball and Jefferson 2004; Meijer 2003; Proud 2004; Xu et al. 2001). However, BCAA and BCAA + Glu did not increase the FSR of dermal tropocollagen (Fig. 3). In addition, other amino acids, such as Arg, Gln, Pro, Arg + Gln, also did not increase the FSR (Fig. 3). This result indicates that while BCAA is important for skin tropocollagen synthesis, other specific amino acids, such as Gln or Pro, are also necessary to stimulate dermal tropocollagen synthesis.

In an in vitro study, Bellon and Karna showed that Gln and its metabolites (glutamate, pyrroline-5-carboxylate, arginine) increase collagen synthesis and suggested that de novo synthesized proline is important for collagen synthesis (Bellon et al. 1995, 1987; Karna et al. 2001). In the present study, the FSR of tropocollagen did not increase when amino acids containing precursors of proline (Gln, Arg, BCAA + Glu and Arg + Gln) were administered, but did increase with an amino acid mixture containing exogenous proline (BCAA + Pro). In addition, plasma proline concentrations were not increased by collagen synthesisstimulating amino acid mixtures containing proline precursors (BCAA + Gln, BCAA + Gln + Arg), but were slightly increased by Arg + Gln and Arg, neither of which stimulated the tropocollagen FSR. These results indicate that de novo proline synthesis is not the main cause of increased collagen protein synthesis. Proline constitutes one-third of collagen protein's amino acid residues. However, there is little information proline supplementation's effect on dermal skin collagen synthesis. Further study is needed to understand the mechanism underlying the effect of BCAA + Pro on the FSR of tropocollagen.

$\mathrm{Xu}$ found that the combination of leucine and glutamine synergistically stimulates the activity of S6K in pancreatic beta cells. Some reports indicate that glutamine regulates protein synthesis (Xu et al. 2001). For example, glutamine restores energy metabolism into cells (Krause et al. 2002b), increases cell swelling (Oehler and Roth 2003), and activates GAPP (glutamate dependent protein phosphatase, which correlates with mTOR activation) (Krause et al. 2002a; Stoll et al. 1992). Arginine also improves wound healing by increasing collagen synthesis; the mechanism of this effect is thought to be the stimulation of growth hormone secretion and nitric oxide synthesis (Stechmiller et al. 2005). Williams reported that an orally administered amino acid mixture consisting of metabolites of leucine (b-hydroxy-b-methylbutyrate), arginine, and glutamine increased the collagen content in subcutaneously implanted tubes in healthy volunteers (Williams et al. 2002). In addition, Corsetti reported that amino acid mixtures that included leucine, proline, lysine, and glycine improved wound healing associated with the modulation of nitric oxidate synthase and transforming growth factor- $\beta 1$ (Corsetti et al. 2010). Dioguardi (2008) also reported that collagen synthesis is efficiently maintained only when specific amino acids are continuously available and present in a specific ratio. Therefore, a possible explanation of our findings is that BCAA + Gln and BCAA + Gln + Arg synergistically stimulate dermal tropocollagen protein synthesis using each amino acid's individual effects on protein synthesis. In addition, insulin is a powerful protein synthesis stimulator, and leucine and arginine stimulate insulin secretion. However, insulin was not the main cause of the increase of the dermal tropocollagen FSR by the amino acid mixtures, because there was no correlation between insulin and the tropocollagen FSR in any group $\left(r^{2}=0.034\right.$; Fig. 6). EAA is known to increase the FSR of skeletal muscle protein (Tipton et al. 1999). In the present study, EAA was the only amino acid observed to increase the FSR of skeletal muscle protein (data not shown). Thus, the tropocollagen FSR improvement resulting from EAA is associated with the improvement of whole-body protein metabolism.

In conclusion, UVB irradiation decreased the FSR of skin tropocollagen, while BCAA + Arg + Gln, BCAA + Gln, BCAA + Pro, and EAA increased the FSR of skin tropocollagen independently of insulin. However, single amino acids and BCAA did not increase the FSR. It should be noted that combinations of specific amino acids, especially BCAA + Gln or BCAA + Pro are vital in stimulating the FSR of skin tropocollagen independently of insulin. However, the dermal collagen protein synthesis stimulation mechanism of these amino acids mixtures is unclear. Further study is necessary to understand the mechanism of the increase tropocollagen FSR by these amino acids.

Acknowledgments We thank Takashi Suzuki, Sayo Inoue, and Shinobu Tanimoto for their assistance with the experimental trial.

Conflict of interest The authors declare that they have no conflict of interest.

Open Access This article is distributed under the terms of the Creative Commons Attribution Noncommercial License which permits any noncommercial use, distribution, and reproduction in any medium, provided the original author(s) and source are credited. 


\section{References}

Anthony JC, Anthony TG, Kimball SR, Vary TC, Jefferson LS (2000) Orally administered leucine stimulates protein synthesis in skeletal muscle of postabsorptive rats in association with increased eIF4F formation. J Nutr 130:139-145

Badiu DL, Luque R, Dumitrescu E, Craciun A, Dinca D (2010) Amino acids from Mytilus galloprovincialis (L.) and Rapana venosa molluscs accelerate skin wounds healing via enhancement of dermal and epidermal neoformation. Protein J 29:81-92

Bellon G, Monboisse JC, Randoux A, Borel JP (1987) Effects of preformed proline and proline amino acid precursors (including glutamine) on collagen synthesis in human fibroblast cultures. Biochim Biophys Acta 930:39-47

Bellon G, Chaqour B, Wegrowski Y, Monboisse JC, Borel JP (1995) Glutamine increases collagen gene transcription in cultured human fibroblasts. Biochim Biophys Acta 1268:311-323

Boyer B, Fourtanier A, Kern P, Labat-Robert J (1992) UVA- and UVB-induced changes in collagen and fibronectin biosynthesis in the skin of hairless mice. J Photochem Photobiol B 14:247-259

Corsetti G, D'Antona G, Dioguardi FS, Rezzani R (2010) Topical application of dressing with amino acids improves cutaneous wound healing in aged rats. Acta Histochem (Germany) 112(5):497-507

Dioguardi FS (2008) Nutrition and skin Collagen integrity: a dominant role for amino acids. Clin Dermatol (United States) 26(6):636-640

Farges MC, Berard MP, Raul F, Cezard JP, Joly B, Davot P, Vasson MP, Cynober L (1999) Oral administration of a glutamineenriched diet before or after endotoxin challenge in aged rats has limited effects. J Nutr 129:1799-1806

Fisher GJ (2005) The pathophysiology of photoaging of the skin. Cutis 75:5-8 (discussion 8-9)

Fisher GJ, Datta S, Wang Z, Li XY, Quan T, Chung JH, Kang S, Voorhees JJ (2000) c-Jun-dependent inhibition of cutaneous procollagen transcription following ultraviolet irradiation is reversed by all-trans retinoic acid. J Clin Invest 106:663-670

Fisher GJ, Choi HC, Bata-Csorgo Z, Shao Y, Datta S, Wang ZQ, Kang S, Voorhees JJ (2001) Ultraviolet irradiation increases matrix metalloproteinase- 8 protein in human skin in vivo. J Invest Dermatol 117:219-226

Garlick PJ, McNurlan MA (1998) Measurement of protein synthesis in human tissues by the flooding method. Curr Opin Clin Nutr Metab Care 1:455-460

Johnstone CC, Farley A (2005) The physiological basics of wound healing. Nurs Stand 19:59-65 (quiz 66)

Karna E, Miltyk W, Wolczynski S, Palka JA (2001) The potential mechanism for glutamine-induced collagen biosynthesis in cultured human skin fibroblasts. Comp Biochem Physiol B Biochem Mol Biol 130:23-32

Kimball SR, Jefferson LS (2004) Regulation of global and specific mRNA translation by oral administration of branched-chain amino acids. Biochem Biophys Res Commun 313:423-427
Krause U, Bertrand L, Hue L (2002a) Control of p70 ribosomal protein S6 kinase and acetyl-CoA carboxylase by AMP-activated protein kinase and protein phosphatases in isolated hepatocytes. Eur J Biochem 269:3751-3759

Krause U, Bertrand L, Maisin L, Rosa M, Hue L (2002b) Signalling pathways and combinatory effects of insulin and amino acids in isolated rat hepatocytes. Eur J Biochem 269:3742-3750

McAnulty RJ, Laurent GJ (1987) Collagen synthesis and degradation in vivo. Evidence for rapid rates of collagen turnover with extensive degradation of newly synthesized collagen in tissues of the adult rat. Coll Relat Res 7:93-104

Meijer AJ (2003) Amino acids as regulators and components of nonproteinogenic pathways. J Nutr 133:2057S-2062S

Oehler R, Roth E (2003) Regulative capacity of glutamine. Curr Opin Clin Nutr Metab Care 6:277-282

Proud CG (2004) mTOR-mediated regulation of translation factors by amino acids. Biochem Biophys Res Commun 313:429-436

Rittie L, Fisher GJ (2002) UV-light-induced signal cascades and skin aging. Ageing Res Rev 1:705-720

Shi HP, Fishel RS, Efron DT, Williams JZ, Fishel MH, Barbul A (2002) Effect of supplemental ornithine on wound healing. J Surg Res (United States) 106(2):299-302

Shi HP, Most D, Efron DT, Witte MB, Barbul A (2003) Supplemental L-arginine enhances wound healing in diabetic rats. Wound Repair Regen (United States) 11(3):198-203

Smriga M, Torii K (2003) L-Lysine acts like a partial serotonin receptor 4 antagonist and inhibits serotonin-mediated intestinal pathologies and anxiety in rats. Proc Natl Acad Sci USA (United States) 100(26):15370-15375

Stechmiller JK, Childress B, Cowan L (2005) Arginine supplementation and wound healing. Nutr Clin Pract 20:52-61

Stoll B, Gerok W, Lang F, Haussinger D (1992) Liver cell volume and protein synthesis. Biochem J 287(Pt 1):217-222

Takema Y, Hattori M, Aizawa K (1996) The relationship between quantitative changes in collagen and formation of wrinkles on hairless mouse skin after chronic UV irradiation. J Dermatol Sci 12:56-63

Tipton KD, Gurkin BE, Matin S, Wolfe RR (1999) Nonessential amino acids are not necessary to stimulate net muscle protein synthesis in healthy volunteers. J Nutr Biochem 10:89-95

Volpi E, Jeschke MG, Herndon DN, Wolfe RR (2000) Measurement of skin protein breakdown in a rat model. Am J Physiol Endocrinol Metab 279:E900-E906

Williams, JZ, Abumrad, N, Barbul, A (2002) Effect of a specialized amino acid mixture on human collagen deposition. Ann Surg 236:369-374 (discussion 374-365)

Xu G, Kwon G, Cruz WS, Marshall CA, McDaniel ML (2001) Metabolic regulation by leucine of translation initiation through the mTOR-signaling pathway by pancreatic beta-cells. Diabetes 50:353-360

Zhang XJ, Chinkes DL, Wolfe RR (2004) Leucine supplementation has an anabolic effect on proteins in rabbit skin wound and muscle. J Nutr 134:3313-3318 